\title{
Precision Nutrition and Metabolic Syndrome Management
}

\author{
Pedro González-Muniesa $1,2,3,4(1)$ and J. Alfredo Martínez $1,2,3,4,5, *$ (i) \\ 1 Centre for Nutrition Research, School of Pharmacy and Nutrition, University of Navarra, 31008 Pamplona, \\ Spain; pgonmun@unav.es \\ 2 Department of Nutrition, Food Science and Physiology, School of Pharmacy and Nutrition, University of \\ Navarra, 31008 Pamplona, Spain \\ 3 IDISNA, Navarra's Health Research Institute, 31008 Pamplona, Spain \\ 4 CIBERobn Physiopathology of Obesity and Nutrition, Centre of Biomedical Research Network, ISCIII, \\ 28029 Madrid, Spain \\ 5 Precision Nutrition Program, IMDEA Food, 28049 Madrid, Spain \\ * Correspondence: jalfmtz@unav.es; Tel.: +34-948-425-600 (ext. 806424)
}

Received: 28 September 2019; Accepted: 6 October 2019; Published: 9 October 2019

Keywords: metabolism; insulin resistance; pathology; therapy; human

The journal NUTRIENTS published some time ago a special issue about "Precision Nutrition and Metabolic Syndrome Management", which included a series of articles about the role of bioactive compounds, amino acids/proteins and fatty acids for personalized nutritional applications [1]. In such volume, the emerging concept of precision nutrition was developed in two specific reviews. These articles explain global personalized nutrition in the management of metabolic syndrome features such as obesity, diabetes, dyslipemia, hypertension and other cardiovascular complications [2], and individualized lipid metabolism targeting in cancer [3]. In particular, they describe the role of nutrigenetics, deep phenotyping, family and personal clinical cues, perinatal nutrition and a wide spectrum of data concerning metabolic personalization through omics technologies (metabolomics, epigenomics, metagenomics, and others), whose possibilities were appraised. Indeed, the conceptual framework understanding precision nutrition is based on assessing the interindividual heterogeneity caused by genetic/epigenetic dissimilarities, the lifestyle and environmental exposome diversity, microbiome variations, and singular behavioral/psychological features [4] with clear implications for public health to harmonize personal and population challenges and applications [5].

In that context, precision nutrition and medicine should consider updated individualized nutritional status indicators for metabolic care and clinical nutrition [6], not only in patients suffering chronic diseases [7] or systemic inflammatory disturbances [8], but also in healthy subjects [9]. Similarly, it is necessary to take into account the development of new transcriptomic biomarkers [10], lipidomic and metabolomic tools [11,12], pharmacogenetic approaches [13] and metagenomic applications [14]. Also, the origins and developmental issues concerning health and disease or epigenetics in line with the developmental origins of health and disease (DOHaD) theory [15] are of interest in precision nutrition [16,17], including specific aspects on obesity [18] and metabolic syndrome features related to liver disease [19].

In the last two years, precision nutrition investigations considering an individual's facets such as age and gender [20], and nutrigenetic interactions associated to genetic variants involving micronutrients such as vitamin E [21], minerals such as iron [22] or caffeine consumption [23] have been addressed by the Journal NUTRIENTS. Furthermore, concerning clinical precision perspectives also the pages of the journal have published articles related with the role of the microbioma on 
precision nutrition [24], the development of personalized biomarkers [25], targeted metabolomics [26], applications for weight management [27], on food allergies [28], or a role on inflammation [29].

Indeed, individualized nutrition integrates information based on genetic/epigenetic background. Nevertheless, personalized clinical and phenotypical features including own psychological/personality patterns, specific food allergies and intolerances, differential cultural, social and environmental backgrounds, drug-side effects, personal dietary preferences as well as singular lifestyle and environmental factors need to be addressed for a solid precision nutrition and medicine. Ethical and regulatory issues are needed to be developed and implemented for a smooth growing of nutrition endeavors and methodologies, where important achievements and challenges are expected for combining public and personal health benefits.

Funding: This research is part of CIBER Physiopathology of Obesity and Nutrition (CIBERobn), Carlos III Health Research Institute (CB12/03/30002) and the Nutrition Research Centre of the University of Navarra.

Conflicts of Interest: The authors declare no conflict of interest. The funders had no role in the design of the study; in the collection, analyses, or interpretation of data; in the writing of the manuscript, or in the decision to publish the results.

\section{References}

1. Martinez, J.A.; Zulet, M.A. Precision Nutrition and Metabolic Syndrome Management, 1st ed.; MDPI: Basel, Switzerland, 2018; pp. 1-211.

2. De Toro-Martín, J.; Arsenault, B.J.; Després, J.P.; Vohl, M.C. Precision Nutrition: A Review of Personalized Nutritional Approaches for the Prevention and Management of Metabolic Syndrome. Nutrients 2017, 9, 913.

3. Aguirre-Portolés, C.; Fernández, L.P.; Ramírez de Molina, A. Precision Nutrition for Targeting Lipid Metabolism in Colorectal Cancer. Nutrients 2017, 9, 1076.

4. Zeisel, S.H. A Conceptual Framework for Studying and Investing in Precision Nutrition. Front. Genet. 2019, 10, 200. [CrossRef] [PubMed]

5. Gil Hernández, Á. Current challenges of nutrition applied research: ¿Person or population? Nutr. Hosp. 2018, 35, 39-43.

6. Taberna, D.J.; Navas-Carretero, S.; Martinez, J.A. Current nutritional status assessment tools for metabolic care and clinical nutrition. Curr. Opin. Clin. Nutr. Metab. Care 2019, 22, 323-328. [CrossRef] [PubMed]

7. Galarregui, C.; Abete, I.; Navas Carretero, S.; Reglero, G.; Ramírez de Molina, A.; Loria Kohen, V.; Zulet, M.Á.; Martínez, J.A.; Consorcio, N. Precision dietary guidelines and ingredients for chronic diseases in pre-senior and senior populations. An. Sist. Sanit. Navar. 2018, 41, 227-242. [PubMed]

8. Solas, M.; Milagro, F.I.; Ramírez, M.J.; Martínez, J.A. Inflammation and gut-brain axis link obesity to cognitive dysfunction: Plausible pharmacological interventions. Curr. Opin. Pharmacol. 2017, 37, 87-92. [CrossRef] [PubMed]

9. Ramos-Lopez, O.; Milagro, F.I.; Allayee, H.; Chmurzynska, A.; Choi, M.S.; Curi, R.; De Caterina, R.; Ferguson, L.R.; Goni, L.; Kang, J.X.; et al. Guide for Current Nutrigenetic, Nutrigenomic, and Nutriepigenetic Approaches for Precision Nutrition Involving the Prevention and Management of Chronic Diseases Associated with Obesity. J. Nutrigenet. Nutrigenom. 2017, 10, 43-62. [CrossRef] [PubMed]

10. Lorente-Cebrián, S.; González-Muniesa, P.; Milagro, F.I.; Martínez, J.A. MicroRNAs and other non-coding RNAs in adipose tissue and obesity: Emerging roles as biomarkers and therapeutic targets. Clin. Sci. 2019, 133, 23-40. [CrossRef]

11. Cantero, I.; Abete, I.; Monreal, J.I.; Martinez, J.A.; Zulet, M.A. Fruit Fiber Consumption Specifically Improves Liver Health Status in Obese Subjects under Energy Restriction. Nutrients 2017, 9, 667. [CrossRef]

12. Ibero-Baraibar, I.; Romo-Hualde, A.; Gonzalez-Navarro, C.J.; Zulet, M.A.; Martinez, J.A. The urinary metabolomic profile following the intake of meals supplemented with a cocoa extract in middle-aged obese subjects. Food Funct. 2016, 7, 1924-1931. [CrossRef] [PubMed]

13. Solas, M.; Milagro, F.I.; Martínez-Urbistondo, D.; Ramirez, M.J.; Martínez, J.A. Precision Obesity Treatments Including Pharmacogenetic and Nutrigenetic Approaches. Trends Pharmacol. Sci. 2016, 37, 575-593. [CrossRef] [PubMed] 
14. Cuevas-Sierra, A.; Ramos-Lopez, O.; Riezu-Boj, J.I.; Milagro, F.I.; Martinez, J.A. Diet, Gut Microbiota, and Obesity: Links with Host Genetics and Epigenetics and Potential Applications. Adv. Nutr. 2019, 10, S17-S30. [CrossRef] [PubMed]

15. Cordero, P.; Li, J.; Nguyen, V.; Pombo, J.; Maicas, N.; Novelli, M.; Taylor, P.D.; Samuelsson, A.M.; Vinciguerra, M.; Oben, J.A. Developmental Programming of Obesity and Liver Metabolism by Maternal Perinatal Nutrition Involves the Melanocortin System. Nutrients 2017, 9, 1041. [CrossRef] [PubMed]

16. Bordoni, L.; Gabbianelli, R. Primers on nutrigenetics and nutri(epi)genomics: Origins and development of precision nutrition. Biochimie 2019, 160, 156-171. [CrossRef] [PubMed]

17. Martínez, J.A.; Cordero, P.; Campión, J.; Milagro, F.I. Interplay of early-life nutritional programming on obesity, inflammation and epigenetic outcomes. Proc. Nutr. Soc. 2012, 71, 276-283. [CrossRef] [PubMed]

18. González-Muniesa, P.; Mártinez-González, M.A.; Hu, F.B.; Després, J.P.; Matsuzawa, Y.; Loos, R.J.F.; Moreno, L.A.; Bray, G.A.; Martinez, J.A. Obesity. Nat. Rev. Dis. Primers 2017, 3, 17034. [CrossRef]

19. Cantero, I.; Abete, I.; Del Bas, J.M.; Caimari, A.; Arola, L.; Zulet, M.A.; Martinez, J.A. Changes in lysophospholipids and liver status after weight loss: The RESMENA study. Nutr. Metab. 2018, 15, 51. [CrossRef]

20. Corella, D.; Coltell, O.; Portolés, O.; Sotos-Prieto, M.; Fernández-Carrión, R.; Ramirez-Sabio, J.B.; Zanón-Moreno, V.; Mattei, J.; Sorlí, J.V.; Ordovas, J.M. A Guide to Applying the Sex-Gender Perspective to Nutritional Genomics. Nutrients 2018, 11, 4. [CrossRef]

21. Galmés, S.; Serra, F.; Palou, A. Vitamin E Metabolic Effects and Genetic Variants: A Challenge for Precision Nutrition in Obesity and Associated Disturbances. Nutrients 2018, 10, 1919.

22. Miranda, M.A.; Lawson, H.A. Ironing out the Details: Untangling Dietary Iron and Genetic Background in Diabetes. Nutrients 2018, 10, 1437. [CrossRef] [PubMed]

23. Southward, K.; Rutherfurd-Markwick, K.; Badenhorst, C.; Ali, A. The Role of Genetics in Moderating the Inter-Individual Differences in the Ergogenicity of Caffeine. Nutrients 2018, 10, 1352. [CrossRef] [PubMed]

24. Mills, S.; Lane, J.A.; Smith, G.J.; Grimaldi, K.A.; Ross, R.P.; Stanton, C. Precision Nutrition and the Microbiome Part II: Potential Opportunities and Pathways to Commercialisation. Nutrients 2019, 11, 1468. [CrossRef] [PubMed]

25. Picó, C.; Serra, F.; Rodríguez, A.M.; Keijer, J.; Palou, A. Biomarkers of Nutrition and Health: New Tools for New Approaches. Nutrients 2019, 11, 1092.

26. Hampel, D.; Shahab-Ferdows, S.; Hossain, M.; Islam, M.M.; Ahmed, T.; Allen, L.H. Validation and Application of Biocrates AbsoluteIDQ ${ }^{\circledR}$ p180 Targeted Metabolomics Kit Using Human Milk. Nutrients 2019, 11, 1733. [CrossRef] [PubMed]

27. Drabsch, T.; Holzapfel, C. A Scientific Perspective of Personalised Gene-Based Dietary Recommendations for Weight Management. Nutrients 2019, 11, 617. [CrossRef]

28. D'Auria, E.; Abrahams, M.; Zuccotti, G.V.; Venter, C. Personalized Nutrition Approach in Food Allergy: Is It Prime Time Yet? Nutrients 2019, 11, 359. [CrossRef]

29. Shivappa, N. Diet and Chronic Diseases: Is There a Mediating Effect of Inflammation? Nutrients 2019, 11, 1639. [CrossRef]

(C) 2019 by the authors. Licensee MDPI, Basel, Switzerland. This article is an open access article distributed under the terms and conditions of the Creative Commons Attribution (CC BY) license (http://creativecommons.org/licenses/by/4.0/). 